\title{
ECONOMIC INSTRUMENTS FOR REDUCTION OF GREENHOUSE GAS EMISSION IN AGRICULTURE AND FORESTRY
}

\author{
Radmilo Pešić' ${ }^{1}$ Marko Ivaniš̌ ${ }^{2}$ Radivoj Prodanovićc ${ }^{3}$
}

\begin{abstract}
Summary
A significant reduction of greenhouse gas emissions in agriculture and forestry can be achieved with adequate economic instruments. There are also other measures on disposal, such as good agricultural practice and organic production that involve the use of agronomic and biotechnological knowledge and skills with the purpose to produce healthy and safe food, with the preserving the environment and production resources.

In the paper we analyze the previous experience in the application of economic instruments for the reduction of greenhouse effect in Agriculture and Forestry, in the broad and narrow sense, both in the domestic and international context. Special attention is given to the experiences in the implementation of the so-called flexibility mechanisms under the Kyoto Protocol. As a result of these experiences, in the period after 2012, new instruments have been created, mainly on a voluntary basis, which does not inspire confidence in their effectiveness.

It has been noted that the system of economic instruments for the promotion of agricultural production in Serbia is in contradiction with the objectives of the climate protection policy.

Changes are proposed in terms of abolishing direct benefits per hectare and the livestock units, as well as introduction of incentives for energy efficiency, renewable energy sources, and specifically for the organic production. Punitive measures must, once and for all, stop the harmful and dangerous practice of burning crop residues on fields.
\end{abstract}

Key words: economic instruments, air, gasses, greenhouse, agriculture.

JEL: Q51, Q 52, Q 54

1 Radmilo Pešić, Ph.D., Full Professor, University of Belgrade, Faculty of Agriculture, Nemanjina 6, 11080 Zemun, Serbia, Phone: +381 1144135 55, E-mail: radmilo@agrif.bg.ac.rs

2 Marko Ivaniš, Ph.D., Associate Professor, University Business Academy in Novi Sad, Faculty of Economics and Engineering Management in Novi Sad, Cvećarska Street no. 2, 21000 Novi Sad, Serbia, Phone: +381 21400 484, E-mail: prof.drmivanis@gmail.com

3 Radivoj Prodanović, Ph.D., Docent, University Business Academy in Novi Sad, Faculty of Economics and Engineering Management in Novi Sad, Cvećarska Street no. 2, 21000 Novi Sad, Serbia, Phone: +381 21400 484, E-mail: rprodanovic@,fimek.edu.rs

EP 2018 (65) 1 (269-291) 


\section{Introduction}

According to the latest estimates (IPCC 2014), annual global GHG emission in agriculture, forestry, and other land uses (AFOLU), in the period from 2000-2010 amounted to about 10-12 $\mathrm{GtCO}_{2}$-eq, or about 24 percent of the total emissions in all the sectors. Specifically, 5-5.8 $\mathrm{GtCO}_{2}$ eq, i.e. about 10-12 percent, of all anthropogenic GHG emissions, originated from agriculture, whereas 4.3-5.5 $\mathrm{GtCO}_{2}$-eq, i.e. 9-11 percent, originated from forestry and other land uses. In absolute terms, these emissions have not significantly changed compared to the emissions registered in the previous (the fourth) report of the IPCC (IPCC, 2007). However, due to the increase in emissions from other sectors, primarily energetics, the share of the observed AFOLU sectors has decreased slightly. In absolute terms, the changes are caused due to the reduction of emissions in developed countries, whereas the emissions have increased in developing countries. In developed countries, the pressure has mainly increased on agricultural land, while deforestation and land degradation have increased in developing countries.

It is believed that AFOLU sectors have a great potential for reducing GHG emissions through afforestation, better land use and better ways of animal husbandry. By the end of this century the AFOLU sectors are expected to become net GHG sinks (Edenhofer et al., 2014). There are high expectations regarding the possibility of GHG reduction in forestry through afforestation and better forest management. It is estimated that the annual reduction potential of forestry in 2030 will range from 0.2 to $13.8 \mathrm{GtCO}_{2}$-eq and from 0.5 to $10.6 \mathrm{GtCO}_{2}$-eq in agriculture, with the expected cost of the reduced carbon from $100 \mathrm{USD} / \mathrm{t} \mathrm{CO}_{2}$-eq (Smith et al., 2014). The possibility of reduction of GHG emissions relative to the demand for agricultural products depending on the change in dietary habits should be added to this significant amount. These possibilities range from 0.7 to $7.3 \mathrm{GtCO}_{2}$-eq per annum in the period around 2050 . In addition, the reduction of losses in food and waste from the food industry could further reduce GHG emissions in the amount of 0.6 to $6 \mathrm{GtCO}_{2}$-eq per annum. Such great potential gives AFOLU sectors an important role in efforts to protect the climate from anthropogenic influences.

In order for such optimistic predictions to be realized, it is necessary to create and implement adequate measures and instruments of practical policies, with the central place belonging to economic instruments.

\section{Methodology and Data Sources}

In research, it is used historical method, graphical method, method of comparative analysis, and are used with other standard methods (analysis and synthesis, generalization and abstraction, induction and deduction, description, logic, etc.).

Data sources include scientific and professional papers, websites, reports the Institute dealing with emissions of greenhouse gases.

\section{Economic instruments}

The term instrument implies the set of arrangements, conducted by a public entity in order to achieve a certain objective. Objectives can be classified into: 
- national and international,

- sectoral,

- ecological,

- socio-economical.

The essential characteristics of these instruments are (Perman, Ma, McGilvray, 1996):

- Efficiency (cost efficiency or economic efficiency);

- Reliability (the extent to which a specific objective can be achieved);

- The level of awareness that the public entity must possess in order to correctly apply the instrument, as well as the costs of obtaining information;

- Long-term consequences (whether the effect of an instrument becomes weaker, stronger, or remains unchanged with time);

- Applicability (which degree of control is necessary to make the instrument effective);

- Dynamic efficiency (whether the application of the instrument creates incentives to increase production quality and reduce harmful emissions);

- Flexibility (the ability to adapt to changed conditions);

- Equity and consequences that the application of the instrument has on income distribution.

Systematic, organized and targeted application of economic instruments is the key component of economic policy measures. In the domain of environmental protection policy, especially climate protection, instruments of quantitative control and marketbased instruments are used.

Quantitative control instruments (regulatory), also known as "prescribe and control", are the oldest and the simplest devices to combat harmful emissions. An example is the EU Nitrates Directive of 1991.

The essence of these instruments is comprised of the following: set objectives in terms of the permitted amount of emissions or the necessary amount of pollution prevention, objective fulfillment control, sanctioning those who do not respect the regulation.

Pecuniary sanctions classify these instruments in the economic group. Their success depends on the efficiency of control, on the one hand, and pecuniary sanctions on the other hand. However, it is necessary to first set pollution standards for each pollutant. It is necessary to establish emission standards for each of the companies, so that the set objective is achieved with minimum costs. This means that marginal reduction costs of combating emissions must be the known for each subject, which requires information on the emitters' cost functions. A state agency or a similar institution that is implementing responsible for combating pollution would struggle to collect all the information. Even if it were in a position to do so, the costs of obtaining such information would be very high and would exceed the benefits of an effective program. This results in the 
practice that quantitative measures to control and combat harmful emissions are usually arbitrarily allocated, which makes the aforementioned programs inferior to marketbased instruments, including the system of taxes and subsidies. Also, as a rule, the low level of incentives on dynamic efficiency accompanies such measures.

Recently, in most countries that practice quantitative measures, setting of objectives in terms of the allowed amount of emissions has been avoided. Instead, maximum concentrations of pollutants in the environment are determined and the requirements for so-called "clean" or "non-carbon" technologies are used as the main instrument to achieve this objective. Regulations that require the application of gas desulfurization on thermal power plant chimneys, catalysts on exhaust systems of motor vehicles, or unleaded petrol are examples of these instruments. It is believed that these instruments are relatively easy to control, easy to use and to rapidly lead to significant reductions in emissions, which makes them a major asset in the fight against pollution in most the OECD member countries. However, they are not always suitable and sometimes can be very inflexible, expensive, and not encouraging to dynamic efficiency.

Market measures for emissions control (economic instruments) in the strict sense include:

\section{1. fiscal measures,}

2. the system of transferable permits.

The advantages of the measures in comparison to the quantitative ones arise from the efficiency of the market mechanism itself to respond quickly to all signals, encourage dynamic efficiency, and lead to a reduction of pollution where the costs are the lowest.

Taxes and subsidies as the basic fiscal instruments, act through the changes in relative prices. Regardless of what is being taxed, either the level of input use or the pollution level, the result amounts to the rise in the cost of a particular process or activity. Subsidies for emission reductions operate in a similar manner. The only difference is that certain activities or production processes are less expensive for the amount of the subsidies paid. From a short-term perspective, taxes and subsidies are symmetrical, while in the long-term there are differences due to the redistributive effects.

Pollution taxes are aimed to achieve pre-defined environmental objectives. These taxes eliminate the difference between social and private costs. In order to achieve an economically acceptable pollution level, tax on each unit of harmful emissions must be equal to the marginal damage at an optimal level of pollution. In this way, external effects are internalized and the polluter is put into the position to take care not only of his own damage costs (private costs) but also of the social damage (external effects on the society). An introduction of eco-taxes is intended to reduce economic activities that disturb the environment to a socially acceptable level.

In case of no social action, the amount of pollution will be much higher since it depends entirely on the will of the polluter, whether it is a company or an individual. However, if a tax on pollutant emissions is introduced, the polluter will reduce the 
harmful activity. In the case of subsidies aimed to encourage cleaner production, the polluter will not reduce the level of activity, but the level of harmful emissions will be reduced. It can be concluded that, from an environmental standpoint, it makes no difference whether we will fight against pollution by taxing harmful activities or by encouraging clean technologies through the subsidies. However, from an economic standpoint, a difference is apparent. The tax will have an impact on the reduction of economic activity (aggregate supply), whereas subsidies will not. However, it cannot be concluded that the subsidies are a superior instrument of the economic policy. Subsidies require a larger budget, which is necessary to be filled in from other sources. Moreover, the experience of the EU countries speaks in favor of taxation, as a suitable instrument for achieving environmental objectives (European Economy, 1992). In this context, an interesting argument is that environmental taxes not only have an ecological function, but may also have a significant fiscal function (filling of the budget), and thus reduceing the need for income tax, which eliminates distortions and encourages growth (Weizsacker, 1989).

The simplest case of pollution taxes is the taxation of GHG emissions which are uniformly distributed in the environment so that the amount of the damage is independent of the place and time of emission. In order for the introduced tax to be an economically efficient instrument, it is necessary that:

1. the tax rate is the same for all pollutants (cost efficiency);

2. the height of the effective tax rate should correspond to the amount of the marginal damage in a socially efficient level of pollution. This is only possible if the state has information about the marginal damage function or the marginal cost function of combating pollution. As this is usually not the case, the tax rate is determined arbitrarily in practice, so the economic efficiency of the instrument is lost. However, even if the environmental policy measures are set in this manner the desired effect will be achieved with minimum costs;

3. whenever it is possible, emissions of harmful substances should be taken as the object of taxation, in particular, GHG emissions, rather than the economic activity itself. In this way, dynamic efficiency and substitution effects are encouraged. For example, if two fuels have the same price per unit of heat they generate, but different environmental effects, introducing a tax on the less favorable fuel reduces its use and consumers are encouraged to substitute it in favor of the one which is more environmentally friendly. Coal and natural gas are an excellent example (Perman, Ma, McGilvray, 1996).

The theoretical model of the system of transferable permits was developed in the late sixties and early seventies (Croker, 1966; Dales, 1968), considerably later than the Pigou's concept of the pollution tax (Pigou, 1920). Therefore it is considered a relatively new instrument. 
In order for the system of transferable permits to function effectively, it is necessary to:

1. determine the amount of pollution that will be allowed. If the efficiency of the system is sought, it is necessary that the total amount of permits issued, measured in the units of pollution, corresponds to an efficient level of pollution. If the regulator (the state) is not able to determine that level or considers that the criterion of efficiency is not adequate for a specific type of pollution, a number of permits can be otherwise defined. For example, with very hazardous pollution, the criterion of economically efficient level would be counterproductive.

2. identify the right of a business to emit a certain kind of pollution only to the extent to which it possesses a permit. Any further emission in excess of the limit must be strictly prohibited.

3. select the criteria for the initial allocation of transferable permits.

4. guarantee the freedom of trading at a price that is freely determined.

The system of transferable permits regulates the quantity of emissions, rather than relative prices. In that sense this instrument is closer to quantitative ones. However, the essential difference lies in the transferability (trade ability) of these permits. If the permit market operates (with the per-determined amount of allowed emissions), the equilibrium permit prices will be created, which indicates that the effect of the instrument would be the same as if a tax at a certain rate was introduced.

If the marginal cost of pollution elimination is higher than the market price of the permit, it pays off more to a single polluter to obtain more rights to pollute, rather than eliminate emissions on its own. At the same time, if another polluter's marginal costs of elimination (purification) of contamination are below the market price, it pays off more to sell the right, (emission permit) to the first polluter and eliminates the pollution on its own. As long as there are differences in marginal costs of eliminating pollution, the trade in permits will take place. When the marginal costs become equal for all the polluters, the permit market will stop operating and the market price will correspond to the level of social shadow-price of the pollution unit, presuming that the regulator opted for the efficient level of emissions. It is, therefore, considered that the system of transferable permits exerts an equal cost-effectiveness as the system of optimal taxation or subsidization. However, the distributional effects of these instruments can be completely different. The reason for this should be sought in the inability to always accurately determine the cost function of combating pollution, as well as in the different criteria in the initial allocation of permits.

The initial allocation of permits may take place, either free of charge, according to the peraccepted criteria, or on the basis of competition among buyers at an auction. In the latter case, the result of the auction will be a transfer of income from polluter in favor of the regulator, in an amount equal to the price of permits multiplied by the allowed amount of emissions.

The system of transferable permits, however, is not suitable for combating emissions that are not uniformly distributed in the environment. Reselling emission permits by polluters 
located inside the sparsely populated area and purchase thereof by polluters which operate in the city core, will cause a significant increase in damages. The situation is similar in cases when the permit is purchased by an emitter located in the dense industrial area from the emitter located in a distant rural area. It can be concluded that the system of transferable permits can be successfully applied only in the case of pollution that is perfectly blended into the environment, such as GHG emissions, which represents the most significant limitation of this otherwise efficient and increasingly popular instrument.

When it comes to mobile sources of pollution, especially means of transportation, measures to control exhaust system are considered effective. Regulations on the mandatory minimum of technical standards (maximum of emissions) related to the use of vehicles are relatively easy to control and apply in the production of new vehicles. As for older vehicles, in which new technical solutions have not been applied, with differentiated rates of tax on the use of motor vehicles or sales tax, customers are encouraged to purchase newer, more environmentally friendly models. However, there are certain doubts surrounding this issue. Although it is quite clear that such measures, e.g. the installation of catalytic converters for exhaust gasses on internal combustion engines, will contribute to the reduction of emissions per kilometer, the overall effect will be reduced only slightly due to the increased use of motor vehicles. At the same time, such measures do not affect the reduction of emissions in critical parts of the day and at critical locations, e.g. in city centers (Pesic, 2012).

The first attempts of a practical application of transferable permits were made during the 1980s in the United States, in order to suppress leaded petrol from the market and eliminate CFC compounds. The most ambitious attempt to control acid rain occurred in the United States, under the IV Amendment of the Clean Air Act of 1990, which introduced a system of transferable permits for emissions of sulfur dioxide, with the intention that, by the year 2000 , emissions of this gas will be reduced by $50 \%$ compared to the level in 1980. The first phase of the $\mathrm{SO}_{2}$ reduction, during which limitations on emissions were placed for 263 biggest polluters, including 110 of thermal power plants, lasted until 1995.The Environmental Protection Agency (EPA) distributed a certain number of permits to each polluter based on the average thermal input in the period from 1985-1987, with the additional possibility of obtaining bonus licenses. Since 1 January 1995, each of the polluters has been allowed to emit $\mathrm{SO}_{2}$ only in quantities for which they hold the license. Non-compliance was punishable by $\$ 2,000$ per ton of emissions, with the obligation to compensate for reduction during the following year. Since the beginning of 2000, almost all power stations using fossil fuels across the United States have been included in this system.

The main advantage of transferable permits is manifested through cost effectiveness. Not only have the expected reductions in $\mathrm{SO}_{2}$ been achieved, but they have also been exceeded. The reductions over those which were planned in 1995 and 1996 led to the creation of reserves, ("permit banks") in the amount of more than 6 million tons of $\mathrm{SO}_{2}$. One of the peculiarities of the US system of transferable permits lies in the possibility of the delayed use of permits and the possibility of forward operations with them. The 
fact remains that the total cost of combating emissions was significantly lower than it would have been the case if the same amount of the reduction was achieved by classical quantitative "prescribe and control" measures. Annual savings are estimated at about $\$ 1$ billion (Stavins, 1998). According to the EPA data, during the program, the volume of transactions in the market was growing; e.g. in 1996, it amounted to more than 4 million tons. The cost of permits in the free market had been falling since the beginning of 1992 , when it amounted to about $\$ 300$ per ton of $\mathrm{SO}_{2}$ emitted, up to about $\$ 70$, at the end of March 1996, with subsequent slight increase, gravitating at around $\$ 100$, not exceeding \$150 (Scmalensee et al., 1998).

The success of this program has undoubtedly contributed to the popularity of marketbased measures, especially the system of transferable permits. The application of economic instruments in the endeavors for the preservation and protection of the climate should be observed in this context.

\section{Economic instruments in the climate protection policy}

A wide range of economic instruments intended for climate protection policy includes:

1. carbon taxes,

2. transferable permits,

3. incentives for the renewable energy sources,

4. incentives for the energy efficiency improvements,

5. introduction of technical standards,

6. subsidies for research, development, deployment and transfer of new technologies.

1. Carbon taxes are introduced in order to prevent negative external effects arising from the combustion of fuels containing hydrocarbons, such as oil and its derivatives, coal, wood, natural gas, etc. The tax on fuels containing carbon increases the cost of energy generated from these fuels, which encourages consumers to reduce their use or switch to the use of energy from alternative sources such as solar, wind, water, etc. The tax rate depends directly on the carbon content per unit amount of fuel (per ton, liter, cubic meter). As the demand for energy becomes more price elastic, i.e. more responsive to changes in price, such an instrument is more effective. This instrument is especially prevalent in European countries that lead a strict policy of climate protection, for example, Sweden, the Netherlands, Finland, Norway, Italy, Great Britain, France, Slovenia, etc. From non-European countries, taxes on carbon were introduced by Canada, in the province of British Columbia. Base levels of these taxes vary from state to state but are most often defined by the quantity and type of fossil fuel. In some states, there are serious political discussions on the tax, its effectiveness, and acceptability. In support of the introduction of the tax on carbon, there is also the possibility of 'recycling' tax revenues, i.e. the use of tax revenue from the carbon tax instead of some other taxes. For example, instead of taxing income, property or investments, it is possible to achieve the necessary budget revenues by taxing "pollution", i.e. GHG emissions. Not only is this 
form of budgetary neutral internalization of negative externalities, but it also provides an incentive for companies and citizens to work more, save more and invest more. In order to avoid taxing, businesses and citizens have an additional incentive to use less energy, introduce new technologies and new energy sources. Although it may seem as rather acceptable, this economic instrument is not politically favored, since it affects the income redistribution and the reduced living standards, as well as the impairment of international competitiveness of energy intensive products (Metcalf, 2009).

2. Transferable permits determine the allowed emission levels, both at the national level and at the level of individual sectors, up to the level of individual enterprises, on the basis of which they are issued. These permits may be an object of transactions between states, but also between enterprises (cap and trade operations). The condition is that each unit of GHG emissions, regardless of who is the emitter, must be covered by permits. Entities which lack permits, and for which it does not pay off to reduce their own GHG emissions, can purchase additional permits from the subjects which find it more profitable to reduce emissions on their own and to sell the permits. The system of transferable permits encourages reduction at the lowest cost.

The disadvantage of this instrument lies in the political weight of the agreement regarding an acceptable level of overall GHG emissions. An even greater problem is the allocation of permits to regions and businesses, causing potential political disagreements. There are two ways of allocating permits. One is the free distribution, according to a generally accepted criterion, for example, according to the registered GHG emissions in the past, and the other is the allocation of permits through auctions, i.e. how much one is willing to pay for a permit. Both types of allocations have their advantages and disadvantages. The problem with free permit allocation (so called "grandfathering") is reflected in the arbitrariness of criteria and possible bias in the administration of the allowed emissions quota. In particular, the question is raised how to allocate permits to the previously nonexistent entities. In allocating quotas through auctions, there is a problem of the additional cost of buying permits. The entities which buy them will always opt to shift burden to the end customers or users of their products, which means that monopolists will always be in a position to pay more and get more emission rights, which will further strengthen their market position and reduce the level of competition.

Problems in the transferable permit system may arise during its controlling, i.e. monitoring and measurement of emissions. There is a problem of whether to measure only emissions that are related to the market activity or to measure all GHG emissions, no matter in which sector they occur, or how to measure changes in land use and forests. Especially delicate is monitoring and sanctioning of violations in the international transferable permits system.

3. Incentives for renewable energy include a wide range of subsidies for producers and users of renewable energy sources. Instead of giving subsidies for fossil fuels, soft loans and tax incentives are given to investments in renewable resources, favorable tariffs to producers of energy from renewables, price subsidies for buyers of renewable 
energy. This instrument is widely used in developed economies, although in different forms and scope.

4. Encouraging efficiency in the production and consumption of energy acts in a similar way to the previous instrument. There are price incentives, favorable loans, favorable tax treatment of investments and profits in initial phase, jointly with the white certificates $^{4}$ use, or $\mathrm{ESCO}^{5}$ (energy service company) arrangements.

5. Technical standards of efficiency consist of an explicit demand towards large producers and users of energy or public companies to apply certain standards of minimum energy efficiency. Any deviation from the standards is considered an offense, which makes this instrument delicate for application because it assumes an objective monitoring which requires an impartial implementing agency. In some countries it is hard to be achieved and separated from the daily political events.

6. Funding for research and development of non-carbon technologies, affirmation of alternative energy sources, and transfer of technology to the underdeveloped world are considered by many authors as one of the most auspicious instruments in the struggle against anthropogenic disturbances of climate on the planet (Harris, 2009; Stern, 2006).

There are firm reasons to believe that with the advent of new technologies, primarily in the energy production and transmission, the true turning point in the policy of climate protection will be reached owing to the fact that the combating GHG emissions will become much cheaper and spontaneously will enter into practice (Pesic, 2012).

\section{The Kyoto Protocol}

Up to date, the biggest global attempt to apply economic instruments on the climate protection policy can be attributed to the Kyoto Protocol and the flexible mechanisms which it defines. At the third Conference of parties that had ratified the United Nations Framework Convention on Climate Change (UNFCCC), in Kyoto in 1997, the most important document in this area - the Kyoto Protocol was adopted. According to the guidelines of this document, all the countries which accepted the responsibility to limit GHG emissions within the first commitment period of the protocol from 2008 to 2012 were listed in the so-called Annex B of the Protocol. Annex A lists the gasses which will be controlled, while Annex B lists the amounts of compulsory reductions in GHG emissions per country. The overall global average of emission reduction amounts to - 5.2 percent relative to the GHG emission level in 1990, which is considered as the base line for the Kyoto Protocol.

The Russian Federation ratified the Protocol on 16 February 2005, which put the Protocol into effect since the preconditions of its implementation had been achieved: that a certain number of countries had adopted it and that it included over $55 \%$ percent

4 Further information on "white certificates": http://www.ewc.polimi.it/documents/EWC brochure.pdf

5 Further information on ESCO arrangements: http://www.esco-europe.com/ 
of all global GHG emissions in $1990^{6}$.

Apart from national programs of GHG reductions, which all the Parties are free to design and implement on their own accord, the Kyoto Protocol also provides a certain degree of flexibility in fulfilling the commitments of the countries listed in the Annex B.

The Protocol provides three so-called flexible mechanisms:

- The international Emission Trade mechanism (ET) was designed for countries of the Annex B group. The Kyoto Protocol allows two of any countries of the aforementioned group to exchange portions of their commitments which results in redistribution of allowed levels of emission. Since GHG perfectly mix in the atmosphere, it is completely irrelevant where the reductions occur, so the International Emission Trade creates globally neutral, but important economic effects. Different countries and regions have different carbon intensities, different energy efficiencies, and different fuel substitution flexibilities. This creates the fact that they also have different marginal costs of emission reduction. The ET mechanism can also include private companies, which can trade among themselves, where the objects of the trade are Assigned Amount Units (AAUs) and Removal Units (RMUs). Purchased AAUs and RMUs could be used for fulfilling commitments in the first commitment period (2008-2012) as well as later, i.e. they can be "saved for the future". When it comes to trade in emissions, it must be taken into account that the Kyoto Protocol emphasizes domestic measures for reducing GHG and that the intention was that all parties should implement actual projects for the purpose of climate protection. As a consequence, there is a limit of the Emission Trade, and the limit of the "'saving for the future" (DeCanio, 2003).

- Joint implementation (JI) was designed to encourage technology transfers and to intensify activities which bind the atmospheric carbon, in the long run, the socalled "carbon sinks". The UNFCCC Annex 1 Parties, and the Kyoto Protocol Annex B Parties, can transfer or exchange Emission Reduction Units (ERU), (so-called "carbon credits") which were issued for joint projects in the field of GHG reductions or strengthening of carbon sinks. Instead of reducing their own emissions, any of the Annex 1 Parties (i.e. Annex B) can invest in the project of reducing GHG in any other country which has also signed the same Annex if it is more cost-effective. This important incentive is justified by the fact that GHG expand in the atmosphere in a perfect way, so from the climatological perspective it is not relevant where the emissions and reductions occur. The basic principles of good JI practice are additionality and a good estimate of initial emission levels. The additionality principle assumes that JI projects must produce higher GHG emissions than those which would occur spontaneously. The estimate of an initial level of emissions is necessary for coordinating parties in JI. The difference

6 The Federal Republic of Yugoslavia ratified the UN Framework Convention on Climate Change in 1997 and the Republic of Serbia as its legal successor ratified the Kyoto Protocol in 2007 
between GHG which would be emitted without a designed project and the amount which would be emitted prior to closing the project present the "saved" emission according to which the ERU are issued. According to the article 2 of the Protocol, every Party is allowed a certain amount of gasses which could have been emitted during the period 2008-2012. When the host country transferred the ERUs to the benefit of the investor country, the carbon credits were deduced from its account and added to the investor's account, which helped to avoid double counting. The Kyoto Protocol required from all of the Annex B Parties to implement national systems for measuring and reporting of emissions and to create national GHG registers. Other requirements were to enable reporting and achieving the predetermined level of emissions in the period 2008-2012 (Pesic, 2004).

- The Clean Development Mechanism (CDM) was designed not only to provide Annex B countries with the possibility to reduce emissions in the countries that have not accepted the aforementioned status but also to help developing countries to achieve sustainable development using foreign investments. CDM projects, whose hosts are the countries which did not accept Annex B, provide the socalled Certified Emission Reductions (CERs), which the industrial countries, i.e. the investors, can use to meet the Protocol requirements. The CDM projects are based on three general criteria: voluntary basis, evidence of long-term benefits, and additionality (Rosales, Pronove, 2002). The CDM projects were expected to provide financing from private, rather than from state sources and to be executed through a partnership between the public and the private sector. Sectors suitable for CDM implementation include the energy sector, processing industry, waste management, forestry, and agriculture. In order for the Annex B countries to achieve the CER, it was necessary for the country where they were registered to have a binding emission quota, accurately calculated according to Protocol requirements and other acts, as well as the national system of GHG accounting. The CDM projects were supposed to be located in countries that have not accepted the commitment to reduce GHG, but have signed the Kyoto Protocol and have institutions for monitoring and control of the projects (Pesic, 2004).

After the first commitment period of the Kyoto Protocol (2008-2012), a conclusion can be drawn that the results are below the expectations. In the period from 2000 to 2010, the overall global emissions increased by about $10 \mathrm{GtCO}_{2}$-eq or at an average rate of 2.2 percent while in the entire period from 1970 to 2000 the average rate was 1.3 percent. The biggest increase was recorded in the energy sector $(47 \%)$, followed by industry (30\%) and traffic (11\%) (IPCC, 2014). The biggest emission decreases occurred in countries in transition, mostly due to transitional recession and not due to successful implementation of climate protection measures (Fig. 1 and 2).

If the calculation includes savings which resulted from carbon sinks formed by land use, the degree of fulfilling the Kyoto Protocol commitments per country is given in figure 1, and if these savings were excluded, the degree is shown in figure 2. 
Figure 1. The Kyoto Protocol fulfillment in the first period (including AFOLU emission savings)

\section{Kyoto successes (blue) and failures (red)}

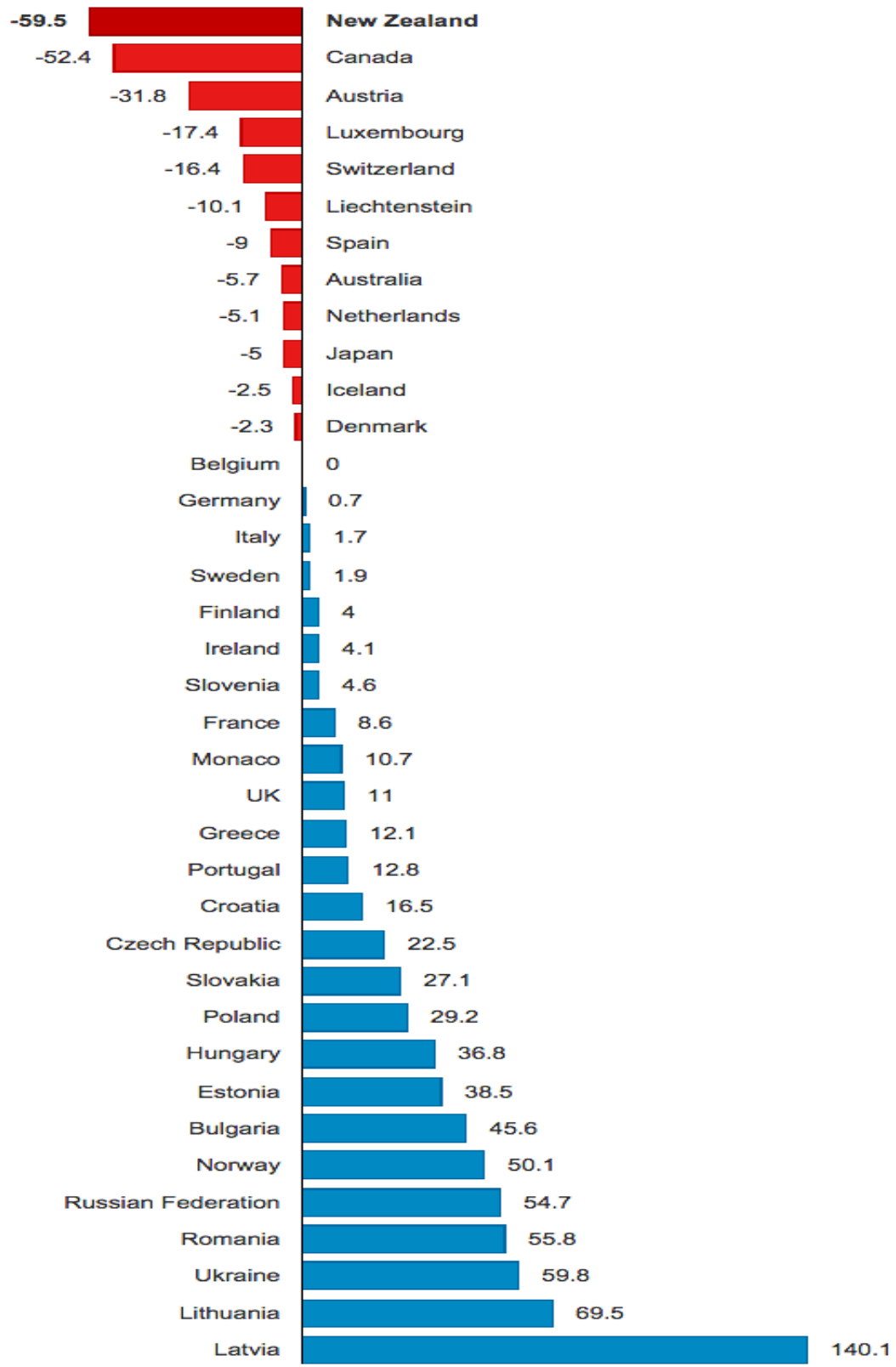

Source:The Guardian 2012 
Figure 2. The Kyoto Protocol fulfillment in the first period (excluding AFOLU emission savings)

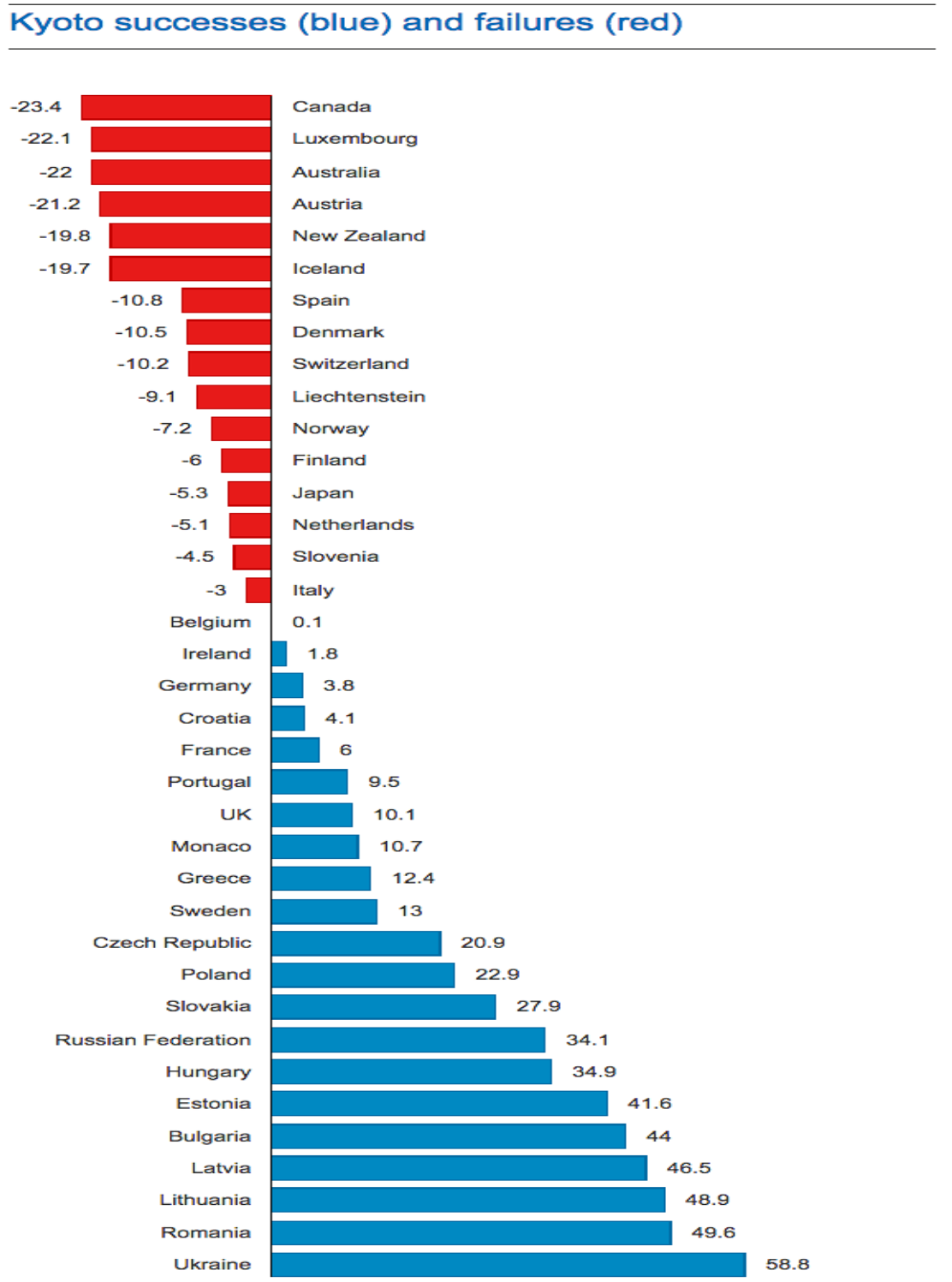

Source: The Guardian 2012

There are some opinions that the Kyoto Protocol has harmed more than it has benefited the GHG reduction (New Scientist, 2013). However, these opinions are isolated since there is a clear evidence that the developed countries which ratified the Protocol decreased the emissions by 22.6 percent in the first commitment period, which presents far more than the proposed commitments (UNFCCC Climate Action, 2015). 
What surely remains as an undisputed contribution of the first commitment phase is the experience in implementation of economic instruments - particularly the CDM mechanism, which opens the door to the further implementation in the following period until 2020 (Schiermeier, 2012).

\section{Instruments for GHG emission reduction in agriculture and forestry after 2012}

Figure 1 shows a much higher degree of fulfillments in certain countries compared to figure 2 , which clearly points to the importance and the potential of sectors related to land use.

Unfortunately, agriculture and forestry are not included in the European Emission Trade Schme (ETS). Although it is the biggest carbon market in the world, the ETS is of no importance to the AFOLU sectors. CDM projects have not focused on these sectors to a wider extent either. Of about 7,000 registered active CDM projects in the world, as little as 2.5 percent is related to agriculture and only 0.6 percent to forestry. To make this absurdity worse, over 90 percent of proposed projects in the developing countries which participate in the NAMA Arrangement ${ }^{7}$ are related to AFOLU (Beckel, 2010). This means that in the next commitment period, by 2020, agriculture and forestry potentials will be used to a higher degree than now, most probably within the CDM arrangements. So far, in AFOLU sectors, projects related to methane reduction. (manure management, biogas, biomass use) and forestry were included in the CDM arrangement. It is expected that in the future the scope of these projects will expand. Experiences from countries such as Australia (Carbon Farming Initiative, The Western Arnhem Land Fire Abatement Project), New Zealand (nitrate fertilizer use reduction, promotion of breeding livestock with obligatory emission monitoring) and California (California emission market, opened in 2012) bring encouraging results.

In the USA, the increase use of voluntary systems of emission trade is becoming more important. By enabling trade in emission reductions on a voluntary basis (Voluntary Emission Reductions, VER), as well as in reduced emissions within CDM projects, the number of participants in the US carbon market has been increasing. Another consequence of the aforementioned activities is the increased depth of the market and the security of the market due to diversification. Large companies from the world of finance and banking, local self-governments, NGOs and other elements of civil society are increasingly in demand for certificates generated in this manner. The value of carbon credit transactions (proof of reduced emissions) from forestry projects in the USA amounted to 133 million USD in 2010, of which 95 percent originated from voluntary activities (Peters-Stanley et al., 2011).

7 Nationally Appropriate Mitigation Actions (NAMA) for suppression of GHG emissions presents a new concept designed for the developing countries in the period after 2012. The idea is that the countries themselves nominate projects in the areas which suit them the most, i.e. the areas which meet their own requirements for sustainable development. This concept was first introduced in the Bali Action Plan in 2007 and is completely integrated into the Cancun Agreement.

EP 2018 (65) 1 (269-291) 
When it comes to the effects of financial instruments in the USA, the most prominent are the so-called weather derivatives, financial instruments in the form of bonds against natural disasters. These securities provide insurance companies with the possibility to neutralize risks of extreme weather conditions. The buyer of the bond sells the insurance against an accident stated in the bond. In other words, they are obliged to pay the seller the insured amount. In contrast, if the disaster does not occur, the seller pays high interest determined by the bond. These bonds became popular in the USA before 2008, so the overall nominal value of weather derivatives in 2006 amounted to 45 billion USD (Ferguson, 2008). After 2011, these stocks increased their presence on financial markets in Great Britain (Speedwell-weather, 2013), and even in India (Kulkarini, Asawa, 2012). The implications of weather derivatives on financial markets are becoming increasingly popular also as a subject of academic discussions (Weagley, 2014).

In developing countries, REDD+ mechanism draws attention. This voluntary instrument is used by the developed countries in order to decrease deforestation and emissions caused by forest degradation, as well as to increase carbon buildup in forests in the developing countries. The instrument was introduced in 2005 at the 11 th Conference of UNFCCC Parties in Montreal. Later, on the 13th Conference, it was integrated into the so-called Bali Action Plan. Since then, this instrument has increasingly been put into practice, introducing two important innovations. The first innovation is reflected in a more intensive engagement with host countries, which are expected to take a more active role in the preparation of national strategies and action plans, raising the capacities for project implementation and technology transfers. The second innovation is reflected in an ex-post approach to finances. This approach is based on project results, or more precisely, on the real GHG reductions and carbon storages, instead of simply expressing the will to make the project successful. The details of ex-post financial flows in REDD+ projects are still subject to amendments and negotiations through various multilateral programs (Forest Carbon Partnership, Forest Investment Program) as well as through bilateral programs (Tanzania-Norway, Indonesia-Norway) (Smith et al., 2014).

There are high expectations regarding REDD+ projects. They are expected to bring to efficient and cost-effective ways of reducing GHG emissions in forestry (Golub et al., 2009).The costs of implementation, especially for monitoring REDD+ projects, will mostly depend on detailed regulations for the sustainable management and certification of forests in host countries. There are open questions in this domain, such as the "GHG drain" from investor countries to host countries, as well as the problem of biodiversity preservation in case of afforestation by highly efficient tree species which grow fast and have an intensive rate of binding carbon from the air.

Among the economic instruments, fiscal instruments are still prominent, e.g. the emission tax, input taxes (fuel, nitrate fertilizers etc.) as well as subsidies for energetic efficiency, carbon substitution, research and development of non-carbon technologies and taxes for certain other measures in AFOLU sectors. Nitrate taxes are especially applied in agriculture and they help to reduce the use of nitrate fertilizers. 
Experience from Sweden is interesting for this domain. Sweden has one of the highest $\mathrm{CO}_{2}$ taxes equal to $1000 \mathrm{SEK} / \mathrm{t} \mathrm{CO}$ (about $110 \mathrm{E} / \mathrm{t}$ ). The tax on nitrate content in mineral fertilizers was introduced in 1984 at the level of $1.80 \mathrm{SEK} / \mathrm{kg} \mathrm{N}$ primarily for the purpose of water protection. Although it showed good results, this instrument was abolished in 2010 to preserve the competitiveness of agricultural production due to planned increase in the $\mathrm{CO}_{2}$ tax. A research (Mohlin, 2013) has shown that the $\mathrm{N}_{2} \mathrm{O}$ emissions would have been bigger by $160 t$ or 2 percent on average if the aforementioned tax had not been introduced; it has also predicted that the abolishment of this tax would completely neutralize the effects of $\mathrm{CO}_{2}$ tax in agriculture. In the same research, it was concluded that the introduction of the tax on cattle products (milk and meat) throughout the $\mathrm{EU}$ at the level of $60 \mathrm{E} / \mathrm{tCO}_{2}$-eq would result in the reduction of GHG emissions by 7 percent (Mohlin, 2013).

Credit allowances for the projects of sustainable development and good practice in agriculture and forestry are complementary to fiscal instruments. Favorable loans are recognized by international financial organizations (GEF - Special Climate Change Fund).

After 2012, there has been a noticeable increase in the voluntary actions regarding climate protection policy, which is no guarantee for efficiency and effectiveness. The 2015 Paris Agreement, declared as a "historic turning point", in fact is far from reaching its aims. Although it may be considered as a big international political success, scientifically speaking it is insufficient and ineffective. Nationally determined contributions, the main Paris agreement instruments, are legally non-binding. They lack the specificity, normative character and compulsion necessary to become legally binding. Without mechanism to force a country to fulfill its declared intentions there will be no success in the international climate protection policy (Druzin, 2016). Also, there is a serious scientific doubt in the $2{ }^{\circ} \mathrm{C}$ reduction targets." Much greater emission reduction efforts will be required in order to hold the increase in the global average temperature to below $2^{\circ} \mathrm{C}$ by reducing emissions to 40 gigatonnes or to $1.5^{\circ} \mathrm{C}^{\prime \prime}$ (UNFCCC Secretariat, 2016). It may be concluded that, by now, the Paris Agreement targets are too weak, and its envisaged governance is uncertain. What will be the future course of its development remains to be seen.

\section{Instruments for GHG emission reduction in Serbian agriculture and forestry}

The overall GHG emissions from Serbian agriculture are estimated to be about 14.126 $\mathrm{GgCO}_{2}$-eq (Znaor, Landau, 2015, pp. 177). However, there is information that the emissions from Serbian agriculture in 2012 totaled as little as $6.45 \mathrm{MtCO}_{2}$-eq or 11.5 percent of overall emissions (WRI, CAIT 2016), and that forests and land absorb up to $75.2 \mathrm{MtCO}_{2}$-eq which means that if AFOLU sectors are included, Serbia was in 2012 a GHG sink rather than an emitter at 19 MtCO $_{2}$-eq (WRI, CAIT 2016). Without questioning the reliability of the data, a conclusion can be drawn that even if more favorable values are accepted given by the World Resource Institute, there was a 3.51 percent increase of emissions by Serbian agriculture in the period between 2006 and 2012 (WRI, CAIT 2016), which also speaks in favor of the importance of Serbian AFOLU sectors for the entire region. 
Unfortunately, the policy of GHG reductions from agriculture in Serbia is given a low priority. The system of economic support for agricultural production is opposed to the goals of climate protection policy. Direct incentives paid to the producers per hectare or per livestock unit are not conditioned by the methods of land cultivation or livestock breeding, which does not raise the producers' concern for GHG emissions.

Subsidies for diesel fuel for agriculture which are about 40 percent of the retail price of diesel, directly encourage agricultural producers to increase fuel consumption, which results in increased emissions, not only of GHG but other harmful substances as well. "Hidden subsidies" for mineral fertilizers present another concern since they encourage the irrational and harmful use of fertilizers. By writing off debts to fertilizer producers on one hand and selling fuel below its market price on the other, the country gives the mineral fertilizer producers the possibility to offer their products at prices which are lower than in the region. This often leads to excessive use of nitrogenous fertilizers, which is the main emitter of nitrogen oxide. Apart from the damage to human health and the wildlife due to high concentration of nitrogen in water and soil, the damage from GHG emissions is estimated to 260 million EUR per annum or to about 55 percent of the overall damage from GHG in Serbian agriculture which is estimated to about 475 million EUR (Znaor, Landau, 2015, pp. 177).

The habit of burning field residue, which is not banned or sanctioned in any way, has even more negative effects. Burning field residue not only emits additional $\mathrm{CO}_{2}$ but it also wastes valuable bio-fuel material and causes a potential danger. A strict law must be introduced to sanction and prevent the practice of burning field residue once and for all.

Serbia needs radical changes in agricultural policy. The inefficient system of direct producer incentives per arable land area and per number of livestock must be abandoned. These incentives mostly suit large farms with conventional production. Bonuses must be given for products of certain quality and technology. Instead of encouraging the intention to produce something, it is necessary to create incentives for environmentally and climate friendly products. Encouraging energy inefficiency and diesel fuel overconsumption must be stopped. On a contrary, it is necessary to suport agricultural producers to use more renewable energy by offering favorable loans and tax incentives. Instead of encouraging the use of mineral fertilizers, it is necessary to encourage organic agriculture, especially in the conversion phase.

Incentives to good agricultural and forestry practice must find their place in the agricultural policy measures. Special attention must be paid to deagrarianization and rural drain in peripheral agricultural regions where there are no preconditions for modern agriculture. These locations require a planned efficient afforestation in order to form a GHG sinks.

8 The damages to the climate as a result of GHG emissions in agriculture have been estimated by expressing all emissions in $\mathrm{CO}_{2}$ equivalent, to which the emission damage price factor of 33.6 EUR/t CO $\mathrm{CO}_{2}$-eq is applied. This damage factor is common in the analyses of the European Environmental Agency (EEA 2011) since it is considered to give a good reflection of the average market price of carbon as well as marginal costs of emission reduction. 
Favourable credit policies and tax incentives should be used to encourage energy production from agricultural and forest biomass. This would be a significant step forward for a stable, decentralized, ecologically friendly energy sector which would serve as a basis for modern society and sustainable agriculture.

\section{Conclusion}

Agriculture, forestry, and other land uses (AFOLU sectors) are still considered very important in the framework of global efforts to preserve the climate. According to the latest IPCC report, global GHG emissions from agriculture, forestry and other of land uses in the period from 2000 to 2010 were about $10-12 \mathrm{GtCO}_{2}$-eq or about 24 percent of overall emissions. The annual potential of GHG decrease around the year 2030 is expected to be between 0.2 and $13.8 \mathrm{GtCO}_{2}$-eq in forestry and between 0.5 and 10.6 $\mathrm{GtCO}_{2}$-eq in agriculture at the expected prices of reduced carbon of $100 \mathrm{USD} / \mathrm{t} \mathrm{CO}$-eq.

In order to utilize the potential, it is necessary to create suitable economic instruments. Of all economic instruments used so far, the central place belongs to the so-called flexible mechanisms of the Kyoto Protocol which together with national programs of GHG reduction form the basis for the effort to prevent anthropogenic climate changes. After the first commitment period, the results were lower than expected. The total global GHG emissions increased in the period from 2000 to 2010 by about $10 \mathrm{GtCO}_{2}$-eq or at an average annual rate of 2.2 percent, while in the entire period between 1970 and 2000, the average rate was 1.3 percent. It is believed that without the Kyoto Protocol and its flexible mechanisms, GHG emissions would have been bigger in the period from 2008 to 2012.

For the period after 2012, there has been a noticeable increase in the voluntary actions regarding climate protection policy, which is no guarantee for efficiency and effectiveness. The current global political climate is not favorable for a globally binding agreement. However, without obligation, there is no significant chance that the commitments will be fulfilled. Moreover, not only is it necessary to establish the legal obligation to implement measures against GHG emissions, but also a straightforward international system of sanctions must be established for those who do not comply. The success of the first commitment period of the Kyoto Protocol would have definitely been more substantial had the sanctions been provided for failure to fulfill the commitment. By now, there is no global political will to do so. Whether such initiatives will appear and when, will depend on the potential damage which may occur in the future due to climate change.

Considering the Serbia, no attention is paid to measures for GHG reductions emissions in agriculture. The system of economic instruments for encouraging agricultural production is opposed to the goals of climate protection policy.

Proposed changes in the agricultural policy include the abolishment of direct incentives per hectare and livestock units, introduction of bonuses for products of certain quality and technology, incentives for energetic efficiency, use of renewable energy sources and for organic production. The incentives for good agricultural and forestry practices must become a standard in agricultural policy. 


\section{References}

1. Bockel, L., Gentien, A., Tinlot, M., and Bromhead, M. (2010). From Nationally Appropriate Mitigation Actions (NAMAs) to Low-Carbon Development in Agriculture: NAMAs as Pathway at Country Level. Food and Agricultural Organization, Rome, Italy, 32 pp. (26 Mart 2016 available at:

http://www.nama-database.org/index.php/)

2. Crocker, T. D. (1966). The Structuring of Atmospheric Pollution Control Systems, in: Harold Wolozin, ed. The Economics of Air Pollution, p. 61-86, New York, Norton.

3. Dales, J. H. (1968). Pollution, Property, and Prices. Toronto, University of Toronto Press.

4. De Canio, S. J. (2003). Economic Models of Climate Change - A Critique. Palgrave Macmillan, New York.

5. Druzin, B. (2016). A Plan to strengthen the Paris Agreement. Fordham Law Review, March, 3.

6. Edenhofer, O., Pichs-Madruga, R., Sokona, Y., Kadner, S., Minx, J. C., Brunner, S., Agrawala, S., Baiocchi, G., Bashmakov, I. A., Blanco, G., Broome, J., Bruckner, T., Bustamante, M., Clarke, L., Conte Grand, M., Creutzig, F., CruzNunez, X., Dhakal, S., Dubash, N. K., Eickemeier, P., Farahani, E., Fischedick, M., Fleurbaey, M., Gerlagh, R., Gomez-Echeverri, L., Gupta, S., Harnisch, J., Jiang, K., Jotzo, F., Kartha, S., Klasen, S., Kolstad, C., Krey, V., Kunreuther, H., Lucon, O., Masera, O., Mulugetta, Y., Norgaard, R. B., Patt, A., Ravindranath, N. H., Riahi, K., Roy, J., Sagar, A., Schaeffer, R., Schlomer, S., Seto, K. C., Seyboth, K., Sims, R., Smith, P., Somanathan, E., Stavins, R., Stechow, von C., Sterner, T., Sugiyama, T., Suh, S., Urge-Vorsatz, D., Urama, K., Venables, A., Victor, D. G., Weber, E., Zhou, D., Zou, J., and Zwickel, T. (2014). Technical Summary. In: Climate Change 2014: Mitigation of Climate Change. The contribution of Working Group III to the Fifth Assessment Report of the Intergovernmental Panel on Climate Change [Edenhofer, O., Pichs-Madruga, R., Sokona, Y., Farahani, E., Kadner, S., Seyboth, K., Adler, A., Baum, I., Brunner, S., Eickemeier, P., Kriemann, B., Savolainen, J., Schlomer, S., Stechow, von C., Zwickel, T. and Minx, J. C. (eds.)]. Cambridge University Press, Cambridge, United Kingdom and New York, NY, USA.

7. European Economy - the Economics of limiting $\mathrm{CO}_{2}$ emission (1992). Special Edition No. 1 Luxemburg.

8. Ferguson, N. (2008): The Ascent of Money. Prevod: Uspon novca, Plato Beograd, 2010.

9. Golub, A., Hertel, T., Lee, H. L., Rose, S., and Sohngen, B. (2009). The opportunity cost of land use and the global potential for greenhouse gas mitigation in agriculture and forestry. Resource and Energy Economics, Vol. 31, 299-319. 
10.Harris, J. M. (2009). Ekonomija životne sredine i prirodnih resursa: savremeni pristup. 2. izd. prevod knjige: Environmental and Natural Resource Economics: A Contemporary Approach, Data Status, Beograd.

11. IPCC (2007). Climate Change 2007: The Physical Science Basis. The contribution of Working Group I to the Fourth Assessment Report of the Intergovernmental Panel on Climate Change. [Solomon, S., Qin, D., Manning, M., Chen, Z., Marquis, M., Averyt, K. B., Tignor, M. and Miller, H. L. (eds.)]. Cambridge University Press, Cambridge, United Kingdom and New York, NY, USA, 996 pp.

12.IPCC (2014). Climate Change 2014: Synthesis Report. The contribution of Working Groups I, II and III to the Fifth Assessment Report of the Intergovernmental Panel on Climate Change [Core Writing Team, R.K. Pachauri and L.A. Meyer (eds.)]. IPCC, Geneva, Switzerland, $151 \mathrm{pp}$.

13. Metcalf, G. E. (2009). Designing a carbon Tax to reduce U.S. Greenhouse Gas Emissions. Review of Environmental Economics and Policy, Vol. 3, No. 1, pp 63-83.

14.Mohlin, K. (2013). Essays on Environmental Taxation and Climate Policy. GoteborgsUniversitet. Handelshogskolan, Department of Economics, Sweden, 155 pp. (26 Mart 2016 available at:

https://gupea.ub.gu.se/handle/2077/33425)

15.New Scientist (2013). (16 Mart 2016 available at:

https://www.newscientist.com/article/dn23041-has-the-kyoto-protocol-donemore-harm-than-good/)

16.Perman, R., Ma, Y., and McGilvray, J. (1996). Natural Resource \& Environmental Economics London and New York, Longman.

17.Pesic, R. (2004). Flexible Mechanisms Under the Kyoto Protocol in Central and Eastern Europe Center for Policy Studies, Budapest, Open Society Institute. (16 Mart 2016 available at:

www.policy.hu/document/200808/pesic.pdf\&letoltes=1)

18.Pesic, R. (2012). Ekonomika životne sredine i prirodnih resursa, Poljoprivredni fakultet, Univerzitet u Beogradu.

19.Peters-Stanley, M., Hamilton, K., Marcello, T., and Sjardin, M. (2011). Back to the Future: State of the Voluntary Carbon Markets 2011. Ecosystem Marketplace $\&$ Bloomberg New Energy Finance, Washington, D. C. and New York, NY, USA.

20.Pigou, A. C. (1920). The Economics of Welfare. London, Macmillan \& Co.

21.Rosales, J., and Pronove, G. (2002). A Layperson's Guide to the Clean Development Mechanism: The Rules from Marrakech. UNCTAD-Earth Council, Carbon Market Programme.

22. Schiermeier, Q. (2012). The Kyoto Protocol: Hot Air Nature, Nov. 28. (16 Mart 2016 available at: 
http://www.nature.com/news/the-kyoto-protocol-hot-air-1.11882\#before)

23.Schmalensee, R., Joskow, P. L., Ellerman, A. D., Montero, J. P., and Bailey, E.M. (1998). An Interim Evaluation of Sulfur Dioxide Emissions Trading. Journal of Economic Perspectives, Vol. 12, No. 3, pp. 53-68.

24.Smith, P., Bustamante, M., Ahammad, H., Clark, H., Dong, H., Elsiddig, E. A., Haberl, H., Harper, R. House, J., Jafari, M., Masera, O., Mbow, C., Ravindranath, N. H., Rice, C. W., Robledo Abad, C., Romanovskaya, A., Sperling, F., and Tubiello F. (2014). Agriculture, Forestry and Other Land Use (AFOLU). In: Climate Change 2014: Mitigation of Climate Change. Contribution of Working Group III to the Fifth Assessment Report of the Intergovernmental Panel on Climate Change [Edenhofer, O., Pichs-Madruga, R., Sokona, Y., Farahani, E., Kadner, S., Seyboth, K., Adler, A., Baum, I., Brunner, S., Eickemeier, P., Kriemann, B., Savolainen, J., Schlömer, S., Stechow, von C., Zwickel, T. and Minx, J. C. (eds.)]. Cambridge University Press, Cambridge, United Kingdom and New York, NY, USA.

25.Stavins, R. N. (1998). What Can We Learn from the Grand Policy Experiment? Lessons from SO2 Allowance Trading. Journal of Economic Perspectives, Vol. 12, No. 3, pp. 69-88.

26.Stern, N. (2006). The Stern Review: The Economics of Climate Change, London HM Treasury.

27. The Guardian (2012). Nov. 26 (16 Mart 2016 available at:

http://www.theguardian.com/environment/blog/2012/nov/26/kyoto-protocolcarbon-emissions)

28.UNFCCC Climate Action (2015). Feb. 16.

(12 Mart 2016 available at:

https://twitter.com/UNFCCC/status/567313128867004417)

29.UNFCCC (2016). Report of the Conference of the Parties on its twenty-first session, held in Paris from 30 November to 13 December 2015 (12 December 2016 available at: http://unfccc.int/resource/docs/2015/cop21/eng/10a01.pdf)

30. Weagley, D. R. (2014). Essays on Weather Derivatives Market. A dissertation submitted in partial fulfillment of the requirements for the degree of Doctor of Philosophy (Business Administration. The University of Michigan, (19 Mart 2016 available at:

https://deepblue.lib.umich.edu/bitstream/handle/2027.42/108993/weagley_1. pdf?sequence $=1$ )

31. Weizsacker, von E.U. (1989). Global Warming and Environmental Taxes. International Conference on Atmosphere, Climate and Man, Torino, Italy.

32.WRI, World Resource Institute, CAIT - Country Greenhouse Gas Emissions Data (28 Mart 2016 available at: http://cait.wri.org/profile/Serbia) 
33.Znaor, D., and Landau, S. (2015). Unlocking the Future - Zameci promene: održiva poljoprivreda kao put prosperiteta za zapadni Balkan. Fondacija „Heinrich Böll”.

\title{
EKONOMSKI INSTRUMENTI SMANJENJA EMISIJE GASOVA SA EFEKTOM STAKLENE BAŠTE U POLJOPRIVREDI I ŠUMARSTVU
}

\author{
Radmilo Pešić ${ }^{9}$, Marko Ivanišs ${ }^{10}$, Radivoj Prodanovićcll \\ Sažetak
}

Značajno smanjenje emisije gasova sa efektom staklene bašte iz poljoprivrede $i$ šumarstva, može se ostvariti jedino uz adekvatne ekonomske instrumente.

U radu se analiziraju dosadašnja iskustva u primeni ekonomskih instrumenata u širem i užem smislu, kako u domaćim, tako i međunarodnim okvirirma. Posebna pažnja se pridaje iskustvima u primeni tzv. fleksibilnih mehanizama iz Kjoto protokola. Kao rezultat tih iskustava, u periodu posle 2012. godine, stvoreni su novi instrumenti, pretežno na dobrovoljnoj bazi, što ne uliva poverenje u njihovu delotvornost.

Konstatuje se da sistem ekonomskih instrumenata za podsticanje poljoprivredne proizvodnje u Srbiji je u suprotnosti sa ciljevima politike zaštite klime.

Predlažu se promene, u smislu ukidanja direktnih davanja po hektaru i broju grla stoke, kao i podsticaji za energetsku efikasnost, upotrebu obnovljivih izvora energije i posebno za organsku proizvodnju. Kaznenim merama se mora, jednom za svagda, prekinuti štetna i opasna praksa paljenja žetvenih ostataka na poljima.

Ključne reči: ekonomski instrumenti, klima, gasovi, efekat staklene bašte, poljoprivreda.

9 Prof. dr Radmilo Pešić, redovni profesor, Univerzitet u Beogradu, Poljoprivredni fakultet, Nemanjina 6, 11080 Zemun, Srbija, Telefon: +381 1144135 55,E-mail: radmilo@agrif.bg.ac.rs

10 Prof. dr Marko Ivaniš, vanredni profesor, Univerzitet Privredna akademija u Novom Sadu, Fakultet za ekonomiju i inženjerski menadžment u Novom Sadu, Cvećarska 2, 21000 Novi Sad, Srbija, Telefon: +381 21400 484, E-mail: prof.drmivanis@gmail.com

11 Doc. dr Radivoj Prodanović, Univerzitet Privredna akademija u Novom Sadu, Fakultet za ekonomiju i inženjerski menadžment u Novom Sadu, Cvećarska 2, 21000 Novi Sad, Srbija, Telefon: +381 21400 484, E-mail: rprodanovic@,fimek.edu.rs

EP 2018 (65) 1 (269-291) 